\title{
Mercury Removal from Aqueous Solutions Using Modified Pyrite: A Column Experiment
}

\author{
Yucheng Zhu ${ }^{1,2}$, Shuchuan Peng ${ }^{1,2, *}$, Ping Lu ${ }^{1,2}$, Tianhu Chen ${ }^{1,2}$ and Yan Yang ${ }^{3}$ \\ 1 School of Resource and Environmental Engineering, Hefei University of Technology, Hefei 230009, China; \\ zhuyucheng0221@163.com (Y.Z.); luping9305@163.com (P.L.); chentianhu@hfut.edu.cn (T.C.) \\ 2 Key Laboratory of Nanominerals and Pollution Control of Anhui Higher Education Institutes, Hefei \\ University of Technology, Hefei 230009, China \\ 3 Civil Engineering, College of Engineering and Informatics, National University of Ireland, H91 TK33 \\ Galway, Ireland; yan.yang@ucd.ie \\ * Correspondence: Pengshuchuan@hfut.edu.cn; Tel.: +86-0551-6290-1523
}

Received: 8 November 2019; Accepted: 27 December 2019; Published: 31 December 2019

\begin{abstract}
Modified pyrite (MPy), which was obtained from calcination in an $\mathrm{N}_{2}$ atmosphere, was used as a sorbent for removing $\mathrm{Hg}$ (II) from aqueous solutions. Fixed-bed column experiments were conducted to determine the $\mathrm{Hg}$ (II) removal ability of MPy from aqueous solutions. MPy was found to be much better than natural pyrite for mercury removal. The concentration of $\mathrm{Hg}$ (II) in effluents was much lower than that of the emission standard used for $\mathrm{Hg}$ wastewater in China $(0.05 \mathrm{mg} / \mathrm{L})$, and the removal efficiency of $\mathrm{Hg}$ (II) was greater than $99 \%$ before breakthrough. When the capacity was 3274 times the column bed volume ( 1 bed volume $\left.=25.12 \mathrm{~cm}^{3}\right)$, the column breakthrough and the sorption amount of $\mathrm{Hg}$ (II) were $54.44 \mathrm{mg} / \mathrm{g}$. The $\mathrm{Hg}$ (II) content in the used MPy sorbent was up to $24.79 \%$. The mechanism was analyzed by X-ray diffraction (XRD), field emission scanning electron microscopy (FE-SEM), field emission transmission electron microscopy (FE-TEM), and X-ray Photoelectron Spectroscopy (XPS). The main mechanism of $\mathrm{Hg}$ (II) removal by MPy was the chemical reactions between mercury ions and mineral fillers, and $\mathrm{HgS}$ precipitated on the surface of MPy to remove $\mathrm{Hg}(\mathrm{II})$. The reaction was also accompanied by surface complexation and adsorption. The results of this work show that MPy can be used as a sorbent for continuous $\mathrm{Hg}$ (II) removal.
\end{abstract}

Keywords: modified pyrite; $\mathrm{Hg}(\mathrm{II})$ removal; fixed-bed column; calcination

\section{Introduction}

Mercury is a hazardous contaminant in wastewater and poses a serious threat to both the environment and public health. The results from past investigations suggest that $\mathrm{Hg}(\mathrm{II})$ is harmful to human health, as it causes a prominent toxic effect on the central nervous system [1,2], renal system [3], immune system [4], cardiovascular system [5-7] and even genetics [8]. Mercury is an element that occurs naturally in the environment, but human activities, such as mining, waste incineration, and chemical production operations also release a huge quantity of mercury into the environment [9]. Since mercury does not degrade naturally, a significant part of mercury that is released into the air, eventually gets deposited in land and water. The mercury deposited into the earth eventually accumulates in the food chain through a series of environmental transport processes. Therefore, a large quantity of mercury gets stored up at the top of local food chains, especially in sharks, swordfish and humans [10].

Mercury emissions data are tracked by the National Emissions Inventory (NEI). According to the statistics, there are 52 tons of mercury emitted into the air per year in the USA. Based on related documentation, the largest source of atmospheric mercury emissions was coal-burning power plants, which it accounted for $44 \%$ of all man-made mercury emissions in the United States in 2014. As per the 
Environmental Protection Agency (EPA), the mercury concentration in treated effluents and potable water must be below $10 \mu \mathrm{g} / \mathrm{L}$ and $2 \mu \mathrm{g} / \mathrm{L}$, respectively [10]. Consequently, $\mathrm{Hg}$ removal from wastewater has attracted great interest from researchers. Numerous treatment technologies commonly used to remove mercury by multiple techniques, such as ion exchange, adsorption, electro-deposition and biological processes have been well developed [11-15]. Among these methods, adsorption was the most widely used because it is cost-effective. A variety of adsorbing materials, such as fruit shell [16,17], activated carbon [18,19], chitosan films [20] and polypyrrole-reduced graphene oxide composites [21], have been studied comprehensively. Recently, natural mineral materials, especially iron sulfide, have gained popularity as adsorbents due to their excellent efficiency and low cost.

Pyrite $\left(\mathrm{FeS}_{2}\right)$ is the most common sulfide mineral around the world and is generally used for the manufacture of sulfuric acid. Recently, pyrite was investigated for $\mathrm{Hg}$ (II) removal because of its high chemical activity. Previous studies on pyrite have confirmed that pyrite can potentially be used for the removal of heavy metals such as $\mathrm{Hg}$ (II) [22,23], $\mathrm{Cu}$ (II) [24,25], $\mathrm{Cd}$ (II) [26,27] and $\mathrm{Pb}$ (II) [28]. However, the ability of natural pyrite to remove heavy metals is restricted by its low sorption capacities as the mineral is characterized by low specific surface area and low chemical reactivity due to strong S-S bonds. These restrictions make the chemical reactivity of pyrite lower than that of pyrrhotite. Pyrrhotite is a kind of nonstoichiometric iron sulfide, which is the most dominant product of pyrite calcination [29]. Former studies have shown that the reaction rates of pyrrhotite oxidation by oxygen was 100 times that of pyrite [30]. Therefore, the authors have created a thermal activation system by calcining natural pyrite to improve its adsorption capacity. Previous studies have shown that calcined pyrite has a high efficiency for use as an adsorbent. Several former experiments conducted by the authors have confirmed the high potential for use MPy (modified pyrite) as efficient adsorbent in heavy metal treatments, both in batch and column experiments. The experimental results are given in Table 1.

Table 1. Comparison of the adsorption capacities of MPy on different heavy metal pollutants.

\begin{tabular}{ccccc}
\hline Heavy Metal Pollutants & $\begin{array}{c}\text { Optimum Calcination } \\
\text { Temperature and Time }\end{array}$ & Experiment Form & $\mathbf{Q}_{\text {max }}(\mathbf{m g} / \mathbf{g})$ & References \\
\hline $\mathrm{Cu}(\mathrm{II})$ & $600{ }^{\circ} \mathrm{C}, 1 \mathrm{~h}$ & Column & 77.42 & {$[28]$} \\
\hline $\mathrm{Pb}(\mathrm{II})$ & $600^{\circ} \mathrm{C}, 1 \mathrm{~h}$ & Column & 73.68 & {$[28]$} \\
\hline $\begin{array}{c}\mathrm{Cu}(\mathrm{II})-\mathrm{Pb}(\mathrm{II})-\mathrm{Cd}(\mathrm{II})-\mathrm{Zn}(\mathrm{II}) \\
\text { multiple solution }\end{array}$ & $600^{\circ} \mathrm{C}, 1 \mathrm{~h}$ & Column & 30.79 & {$[28]$} \\
\hline $\mathrm{Hg}(\mathrm{II})$ & $60{ }^{\circ} \mathrm{C}, 0.5 \mathrm{~h}$ & Batch & 166.67 & {$[31]$} \\
\hline $\mathrm{Eu}(\mathrm{III})$ & $650{ }^{\circ} \mathrm{C}, 1.5 \mathrm{~h}$ & Batch & 10.03 & {$[32]$} \\
\hline $\mathrm{Phosphorus}$ & $600{ }^{\circ} \mathrm{C}, 1 \mathrm{~h}$ & Batch & 5.36 & {$[33]$} \\
\hline Phosphorus & $600^{\circ} \mathrm{C}, 1 \mathrm{~h}$ & Column & 0.17 & {$[33]$} \\
\hline
\end{tabular}

In this work, a column experiment was designed to explore the efficiency of using MPy as a mineral sorbent by comparing its performance with that of natural pyrite and to investigate the feasibility of using MPy for $\mathrm{Hg}$ (II) removal. The capacities and mechanisms of MPy for adsorbing $\mathrm{Hg}$ (II) were studied by using surface analysis techniques including SEM, XRD, TEM and XPS. The experimental results reveal the feasibility of using MPy for the removal of mercury.

\section{Materials and Methods}

\subsection{Materials}

The natural pyrite (Py) used in this experiment was obtained from the Xinqiao Mine, Anhui Province, China. The material was crushed and ground to fraction of $0.5-1 \mathrm{~mm}$. Subsequently, the sample was soaked in $5 \% \mathrm{HCl}$ for $2 \mathrm{~h}$ to wash away the impurities and oxide film on the surface. Finally, the sample was washed by deionized water. The obtained samples were dried using an electric 
vacuum drying oven in an anoxic environment. After that, the purified pyrite was calcined at $600{ }^{\circ} \mathrm{C}$ for $30 \mathrm{~min}$ in an $\mathrm{N}_{2}$ atmosphere.

The solution with a low concentration of $\mathrm{Hg}(\mathrm{II})$, used in the experiment, was prepared with deionized water containing dissolved $\mathrm{Hg}\left(\mathrm{NO}_{3}\right)_{2}$. The $\mathrm{Hg}$ (II) concentration in the solution was $0.165 \mathrm{mmol} / \mathrm{L}$, and the $\mathrm{pH}$ was adjusted to 3 for preservation [34].

\subsection{Column Experiments}

Two glass pipe columns of $60 \mathrm{~cm}$ height and $10 \mathrm{~mm}$ inner diameter were used to perform the sorption experiments. The column was filled to the height of $5 \mathrm{~cm}$ from the bottom with broken glass, which was used as the supporting layer to prevent the leakage and loss of experimental materials during the operation. One column was packed to a $32 \mathrm{~cm}$ with $50 \mathrm{~g}$ of Py, while the other to the same height with $50 \mathrm{~g}$ of MPy. Mercury concentration in the influent solution was $33.09 \mathrm{mg} / \mathrm{L}$ and the $\mathrm{pH}$ equal to 6.82. The experimental apparatus was illustrated in Figure 1. When the experiment started, the solution was constantly pumped to the column with a flow rate equal to $0.8 \mathrm{~mL} / \mathrm{min}$ from the reservoir tank containing the waste water to the bottom inlet of the column with a speed-controllable peristaltic pump system, and the calculated hydraulic retention time (HRT) was on the level of $31.4 \mathrm{~min}$. The breakthrough $\mathrm{Hg}$ (II) concentrations were set at $0.05 \mathrm{mg} / \mathrm{L}$, which is the upper limit of the national sewage comprehensive emission standard for $\mathrm{Hg}$ wastewater in China (GB 8978-1996) [35].

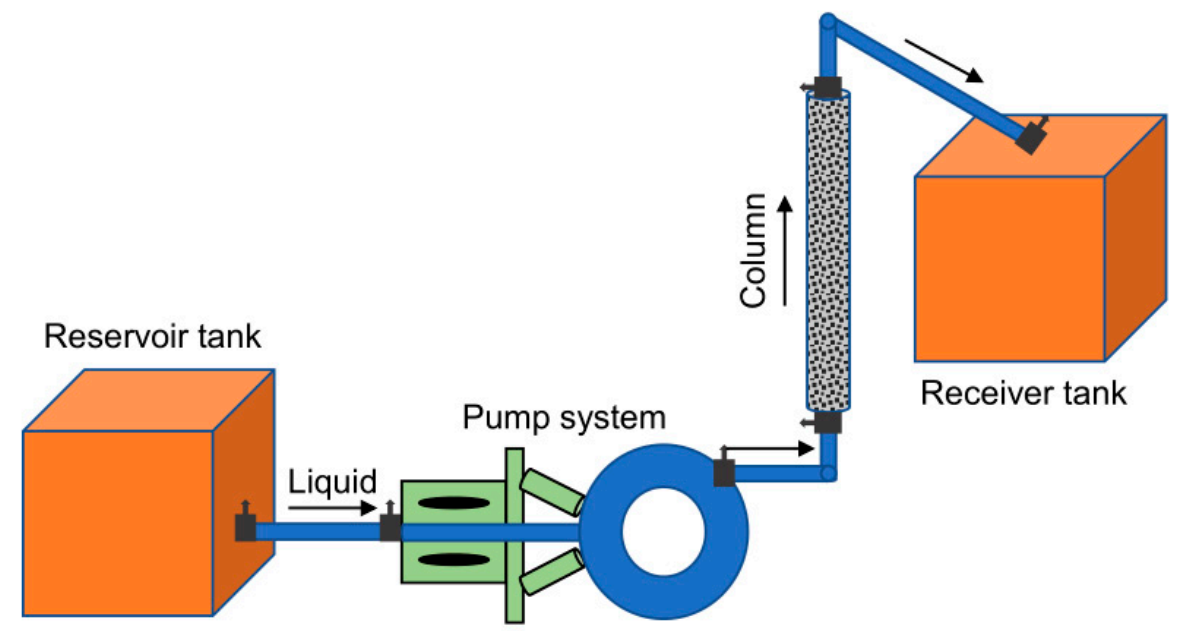

Figure 1. Experimental schematic diagram of the column.

\subsection{Analysis and Characterization}

Every day, the $\mathrm{pH}$ of the effluent was determined by a portable $\mathrm{pH}$ meter, and then, the effluent was filtered through $0.45 \mu \mathrm{m}$ filter paper. The ion content of $\mathrm{Hg}$ (II) in the discharged effluent was analyzed by using a direct mercury analyzer (DMA-80, Milestone, Italy). The Fe(II) concentrations were measured by phenanthroline spectrophotometry using a spectrophotometer (SP-722E, CANY, Shanghai, China), and the sulfate radical concentrations were examined by ion chromatography using an ion chromatograph (IC6100, Wayeal, Hefei, China).

At the very moment the breakthrough occurred in the columns, the input of the mercury-containing wastewater was stopped. Next, the columns were rinsed in deionized water for $5 \mathrm{~h}$ to remove the mercury attached to the surface of the products. Then, those columns were sealed and placed in a freezer. After that, the frozen fillers were extracted from the columns by tapping the column carefully with a hammer to peel the glass but not damage the filler, which ensured that the stuffing inside remained intact. Then, the fillers were divided into $162 \mathrm{~cm}$ long sections, along with the columns from the bottom to the top. Finally, those samples were dried in a vacuum freeze drying oven and sealed in an oxygen-free condition to further analyze their chemical and mineral compositions. 
The following techniques were applied to identify the sample compositions: X-ray diffraction (XRD, DX 2700, Haoyuan Instrument, Dandong, China)was used to of analyze the phase changes of the raw materials and reaction products, X-ray Photoelectron Spectroscopy (XPS, ESCALAB250Xi, Thermo Fisher Scientific, Massachusetts, USA) was used to detect the form of mercury in the reaction products, field emission scanning electron microscopy (FE-SEM, SU8020, Hitachi, Tokyo, Japan) should be able to examine the morphology changes of the samples, and field emission transmission electron microscopy (FE-TEM, JEM-2100F, JEOL, Tokyo, Japan) indicates the crystalline characteristics of the reaction products.

\section{Results and Discussion}

\subsection{Structure and Property of Modified Pyrite}

Figure 2A shows the XRD patterns of the fillers of the two samples. Diffraction peaks are observed at $2 \theta=28.51^{\circ}, 33.08^{\circ}, 37.11^{\circ}, 40.78^{\circ}, 47.41^{\circ}, 56.28^{\circ}, 61.69^{\circ}$ and $64.28^{\circ}$, which correspond to the peak of the standard card of pyrite (JCPDS: 42-1340). Figure 2 exhibits a small peak, which indicates that the pyrite sample also contains a small amount of quartz (JCPDS: 46-1045). The peaks at $2 \theta=30.02^{\circ}$, $34.02^{\circ}, 44.04^{\circ}, 53.28^{\circ}, 57.17^{\circ}$ and $65.52^{\circ}$ are the characteristic peaks of pyrrhotite (JCPDS: 24-0220). The XRD peaks characteristic of Pyr are wide and weak compared to those of Py, and their presence implies the low crystallinity and smaller particle size of the sample. A quantitative estimation of the average grain sizes of the pyrrhotite microcrystallites was obtained from the broadening of the XRD peaks according to Scherrer's formula (1):

$$
\mathrm{D}=\frac{\mathrm{K} \gamma}{\mathrm{B} \cos \theta}
$$

where $\mathrm{D}$ is the crystal size, $\mathrm{K}$ is the Scherrer constant $(\mathrm{K}=0.89), \gamma$ is the wavelength of the $\mathrm{Cu} K_{\alpha}$ radiation $(\gamma=0.154 \mathrm{~nm}), \mathrm{B}$ is the observed diffraction broadening, and $\theta$ is the Bragg angle (in degrees). The results show that the average crystal sizes of the pyrrhotite is $21.9 \mathrm{~nm}$.
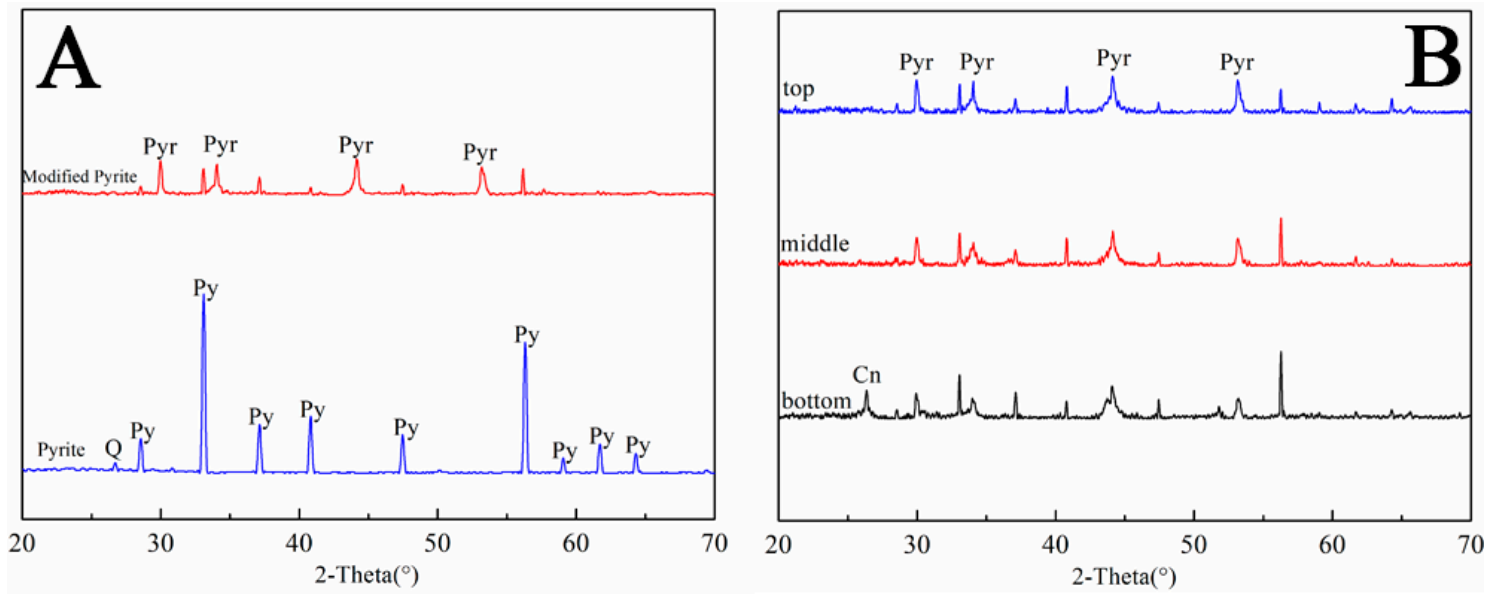

Figure 2. XRD patterns of the (A) fillers of the two columns before the experiments (Py: pyrite; Pyr: pyrrhotite; Q: quartz) and (B) three samples at the bottom, middle and top of the MPy column (Pyr: pyrrhotite; Cn: cinnabar).

A pyrite peak was also observed in the calcined pyrite sample XRD pattern, indicating the presence of a small amount of pyrite that was not completely calcined.

Figure 3 show the SEM images of Py (A) and MPy (B). It can be observed that the natural pyrite crystal has a large size with smooth surfaces, while the modified pyrite has abundant inhomogeneous pores, resulting in modified pyrite with a higher porosity and higher specific surface area than natural pyrite, which confirms the result obtained from previous studies [31-33]. 


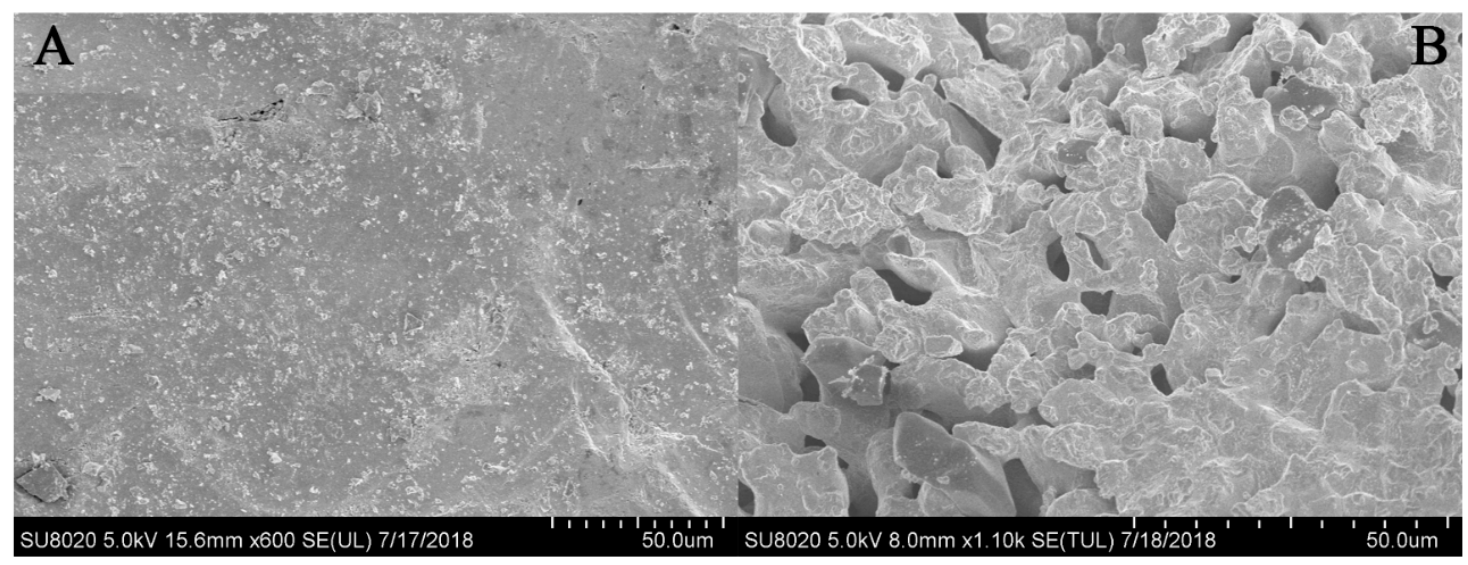

Figure 3. (A) SEM image of natural pyrite and (B) SEM image of modified pyrite.

Based on previous studies by the authors, the sorption process of $\mathrm{Hg}$ (II) by MPy can be fitted by the Langmuir model and the Freundlich model. The Langmuir isotherm $\left(R^{2}=0.9991\right)$ fit better than the Freundlich isotherm $\left(R^{2}=0.9724\right)$ with regards to the sorption of $\mathrm{Hg}$ (II) onto MPy, and the maximum adsorption capacity of $\mathrm{Hg}$ (II) is $166.67 \mathrm{mg} / \mathrm{g}$ [31]. The specific surface area of MPy can be calculated from formula (2):

$$
\mathrm{S}_{\mathrm{g}}=\frac{\mathrm{V}_{\mathrm{m}} \mathrm{NA}}{22400 \mathrm{~W}} \times 10^{-18}
$$

where $S_{g}$ is the specific surface area of crystal, $V_{m}$ is the monolayer adsorbed nitrogen quantity, $\mathrm{N}$ is the Avogadro constant, $\mathrm{A}_{\mathrm{m}}$ is the cross-sectional areas of adsorbed nitrogen, and $\mathrm{W}$ is the weight of the sample. The specific surface area of MPy is $581.34 \mathrm{~m}^{2} / \mathrm{g}$, which confirmed the higher sorption capacity of MPy.

\subsection{Performance of MPy for $\mathrm{Hg}(\mathrm{II})$ Removal in the Column Experiment}

\subsubsection{Effluent Analysis}

Figure $4 \mathrm{~A}$ shows the variation of the $\mathrm{Hg}$ (II) concentrations in the column effluent with respect to the column bed volume (BV, $\left.1 \mathrm{BV}=25.12 \mathrm{~cm}^{3}\right)$. The results reveal that MPy has a high chemical affinity for $\mathrm{Hg}$ (II), and the breakthrough volume is up to $3274 \mathrm{BV}$. The $\mathrm{Hg}$ (II) concentrations of the MPy column effluent are lower than $0.05 \mathrm{mg} / \mathrm{L}$ when the handling capacity is less than $3274 \mathrm{BV}$, and the removal rate remains above $99 \%$. However, for the natural pyrite, the $\mathrm{Hg}$ (II) breakthrough volume is approximately $127 \mathrm{BV}$, which indicates its inefficiency in mercury adsorption. A univariate test showed that the $\mathrm{Hg}$ (II) concentrations in the effluents of the MPy and Py columns were significantly different at a $1 \%$ significance level $\left(P\right.$-value $=2.42 \times 10^{-28}$ ) as BV increased, and the growth rate of the $\mathrm{Hg}$ (II) concentration in the effluent of the Py column was obviously higher than that in the effluent of the MPy column. The experimental results show that the modified pyrite has a better ability than natural pyrite to remove $\mathrm{Hg}$ (II) from water. The analysis of variance showed the time had a significant effect on the $\mathrm{Hg}(\mathrm{II})$ concentration in the effluent of the MPy column $\left(\mathrm{P}\right.$-value $\left.=2.24 \times 10^{-37}\right)$. 

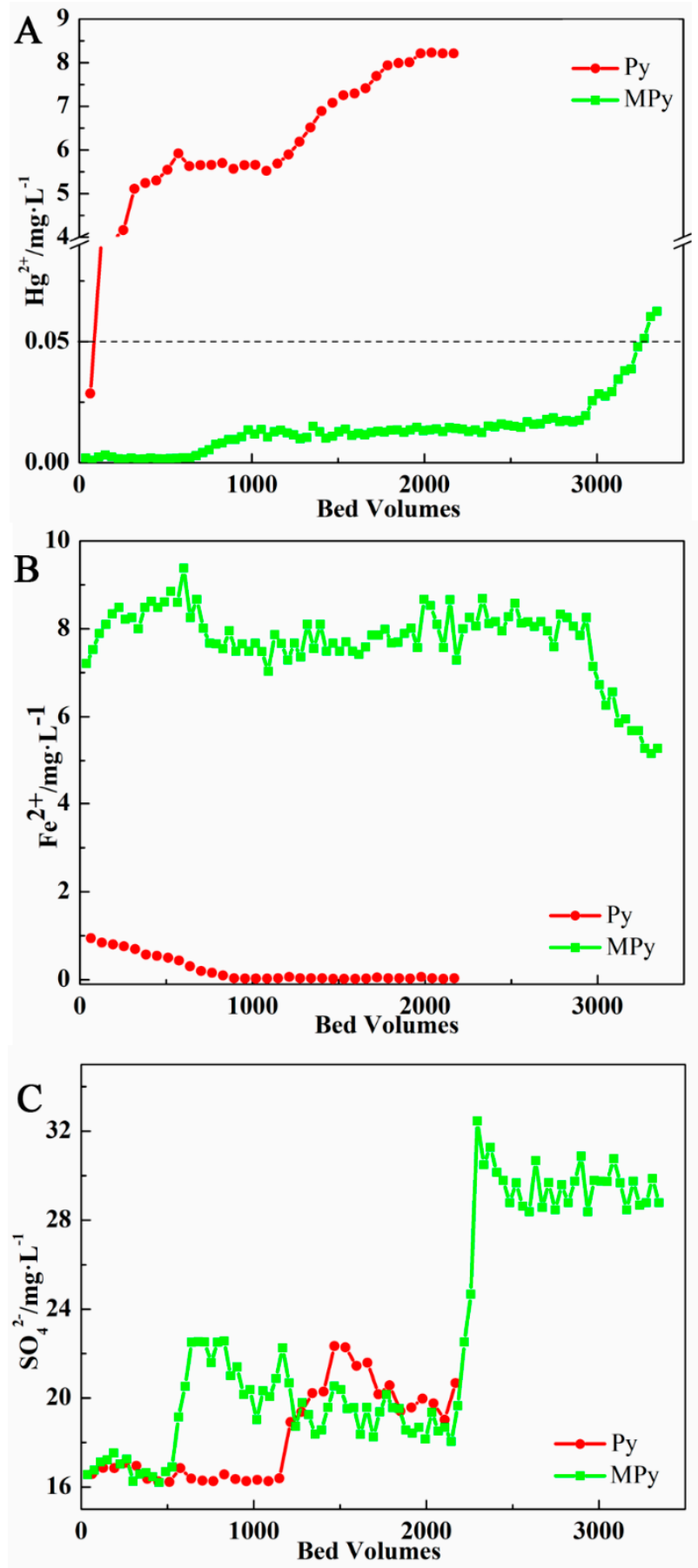

Figure 4. The concentrations of (A) $\mathrm{Hg}(\mathrm{II}) ;\left(\right.$ B) $\mathrm{Fe}(\mathrm{II})$ and (C) $\mathrm{SO}_{4}{ }^{2-}$ in the effluent of columns.

Figure $4 \mathrm{~B}$ shows the variation of the $\mathrm{Fe}(\mathrm{II})$ concentrations in the column effluent with respect to the column bed volume. It can be seen that the Fe(II) concentrations are approximately $0.95 \mathrm{mg} / \mathrm{L}$ in the initial stage of the Py column and decreases rapidly during the experiment. When the volume is up to $893 \mathrm{BV}$, the Fe(II) concentrations drop to the minimum. This result corresponds to the rising trend of mercury concentrations. In the initial running stage of the MPy column, a large amount of $\mathrm{Fe}(\mathrm{II})$ is detected in the effluent, with concentrations of $8.1 \mathrm{mg} / \mathrm{L}$, which is almost the same as the $\mathrm{Hg}$ (II) concentration in the influent. When the volume reaches $2930 \mathrm{BV}$, the $\mathrm{Fe}(\mathrm{II})$ concentrations in the effluent decrease rapidly, corresponding to the variation trend of $\mathrm{Hg}$ (II) concentrations. A univariate test showed that the Fe(II) concentrations in the effluents of the MPy and Py columns were significantly 
different at a $1 \%$ significance level $\left(\mathrm{P}\right.$-value $=2.21 \times 10^{-67}$ ) as the $\mathrm{BV}$ increased. As the experiment progressed, $\mathrm{Hg}(\mathrm{II})$ was continuously attached to the surface of the MPy column, and $\mathrm{HgS}$ precipitated on the material surface, which inhibited the release of Fe(II), leading to the gradual reduction in the $\mathrm{Fe}(\mathrm{II})$ concentration in the effluent and a gradual reduction in the $\mathrm{HgS}$ precipitation rate until the MPy column lose its reactivity. The analysis of variance showed the time had a significant effect on the $\mathrm{Fe}(\mathrm{II})$ concentration in the effluent of the MPy column $\left(P\right.$-value $\left.=3.64 \times 10^{-37}\right)$.

Figure $4 \mathrm{C}$ shows the variation of the $\mathrm{SO}_{4}{ }^{2-}$ concentrations in the column effluent with respect to the column bed volume. The concentrations of $\mathrm{SO}_{4}{ }^{2-}$ in both the columns were relatively high throughout the experiment, which indicated the existence of an obvious oxidation phenomenon, and the variation trend of the $\mathrm{SO}_{4}{ }^{2-}$ concentrations corresponded to the change in the $\mathrm{Hg}$ (II) concentrations. At the initial operation stage, the concentrations of $\mathrm{SO}_{4}{ }^{2-}$ remained stable at 16.5 and $17.0 \mathrm{mg} / \mathrm{L}$. As the $\mathrm{Hg}$ (II) concentrations increased, the $\mathrm{SO}_{4}{ }^{2-}$ concentrations in the effluent rose to 20.5 and 20.3 $\mathrm{mg} / \mathrm{L}$. When the $\mathrm{Hg}$ (II) concentrations increased rapidly until breakthrough was achieved, the $\mathrm{SO}_{4}{ }^{2-}$ concentrations of the MPy column increased sharply and stabilized at $29.7 \mathrm{mg} / \mathrm{L}$. The analysis of variance showed the time had a significant effect on the $\mathrm{SO}_{4}{ }^{2-}$ concentration in the effluent of the MPy column $\left(\right.$ P-value $\left.=9.4 \times 10^{-37}\right)$

\subsubsection{Capacity Analysis}

When breakthrough happened in the column, the content of $\mathrm{Hg}(\mathrm{II})$ eliminated from the influent by MPy was calculated using Equation (3):

$$
Q=\frac{F \int_{t=0}^{t}\left(C_{1}-C_{2}\right) d t}{M}
$$

$C_{1}$ and $C_{2}$ are the effluent and influent concentrations of $\mathrm{Hg}(\mathrm{II}), \mathrm{t}(\mathrm{d})$ was the elapsed time of the column before breakthrough, $\mathrm{F}(\mathrm{L} / \mathrm{d})$ is the inlet velocity of the influent, and $\mathrm{M}(\mathrm{g})$ is the mass of the adsorbent filled in the column.

Before breakthrough, $\mathrm{C}_{1}$ was $33.09 \mathrm{mg} / \mathrm{L}$, and $\mathrm{C}_{2}<0.05 \mathrm{mg} / \mathrm{L}$, so we can simplify Equation (4) as follows:

$$
\mathrm{Q}=\frac{\mathrm{FC}_{1} \mathrm{t}}{\mathrm{M}}
$$

When column breakthrough occurred, the sum of the $\mathrm{Hg}$ (II) amount adsorbed on the Py and MPy particulates in the column were approximately 0.19 and $54.44 \mathrm{mg} / \mathrm{g}$. MPy is a much more efficient sorbent material than Py for the continuous treatment of $\mathrm{Hg}$ (II) removal. Compared to wet chitosan spheres and rice husk ash whose sorption capacities for $\mathrm{Hg}$ (II) are $17.27 \pm 0.9 \mathrm{mg} / \mathrm{g}$ and $3.2 \mathrm{mg} / \mathrm{g}$, MPy is an effective natural sorbent for $\mathrm{Hg}$ (II) removal [36,37].

\subsubsection{Variation of the Mercury and Iron Contents}

Figure 5 shows the variation of the mercury and iron contents in the solid products with respect to the column height after the products penetrated the two columns, and the change trend of the $\mathrm{Hg}$ (II) content in the products is basically opposite to that of the Fe(II) content. From the bottom up, the content of $\mathrm{Hg}$ (II) decreased, and the content of Fe(II) increased gradually in the column. The $\mathrm{Hg}$ (II) content and $\mathrm{Fe}$ (II) content in Py did not change significantly as the column height increased, which corresponds to the low treatment capacity of Py. As the column height increased, the $\mathrm{Hg}$ (II) content in the MPy column gradually decreased from $133.54 \mathrm{mg} / \mathrm{g}$ on the bottom to $16.15 \mathrm{mg} / \mathrm{g}$ on the top, while the Fe(II) content increased from $139.95 \mathrm{mg} / \mathrm{g}$ to $560.73 \mathrm{mg} / \mathrm{g}$. The analysis of variance showed that the height of the MPy column had a significant effect on the $\mathrm{Hg}$ (II) concentration (P-value $=7.33 \times 10^{-4}$ ) and $\mathrm{Fe}(\mathrm{II})$ concentration (P-value $=9.79 \times 10^{-11}$ ). According to the curve shown in the figure, $\mathrm{Hg}$ (II) is mainly adsorbed at the bottom of the column, which was the inlet of the influent. Meanwhile, more iron dissolved at the bottom of the dynamic column. $\mathrm{The} \mathrm{Hg}(\mathrm{II})$ in the bottom sample of the MPy 
column accounted for $24.79 \%$ of the total weight. MPy column is an extremely efficient material for $\mathrm{Hg}(\mathrm{II})$ adsorption in aqueous media.
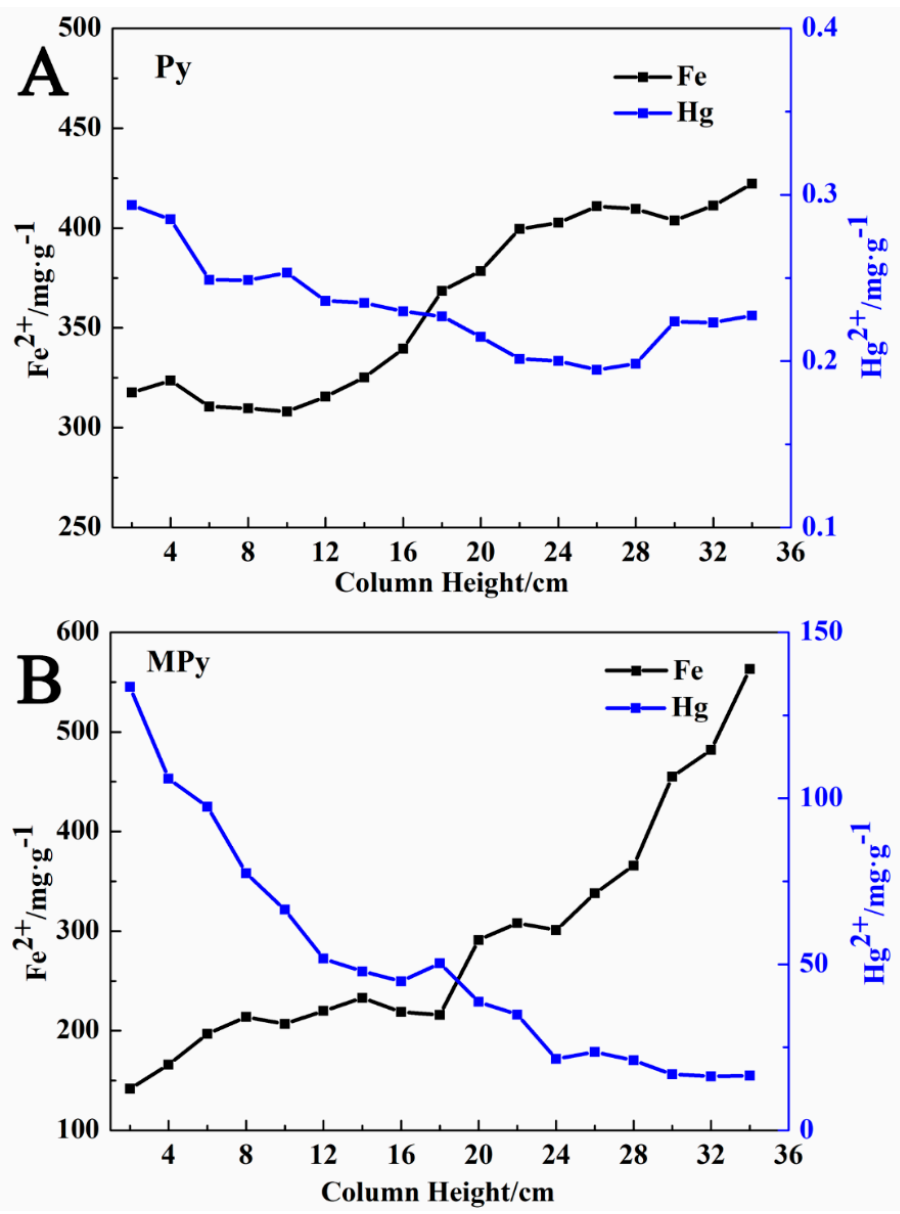

Figure 5. Variation of the $\mathrm{Hg}(\mathrm{II})$ and $\mathrm{Fe}(\mathrm{II})$ contents with respect to the column height (A) of the Py column and (B) MPy column.

\subsubsection{XRD Analysis}

XRD was used to identify the major mineralogical composition of the MPy sampled from the bottom, middle, and top of the column. Figure 2B shows that pyrrhotite is the major phase after breakthrough occurred, and the characteristic peak of cinnabar $(\alpha-\mathrm{HgS})$ appeared in the XRD pattern of the sample at the bottom of the column. As the dynamic column height increased, the characteristic peak of $\mathrm{HgS}$ disappeared, and the diffraction peak corresponding to pyrrhotite strengthened gradually. Thus, it is apparent that $\mathrm{HgS}$ is produced by the reaction between $\mathrm{Hg}(\mathrm{II})$ and MPy in the solution at the bottom of the column. The results show that a significant amount of $\mathrm{HgS}$ was adsorbed on the MPy surface. The dissolution of $\mathrm{Fe}_{1-\mathrm{x}} \mathrm{S}$ and the formation of $\mathrm{HgS}$ can be described as follows [38]:

$$
\begin{gathered}
\mathrm{Fe}_{1-\mathrm{x}} \mathrm{S}_{(\mathrm{s})} \leftrightarrow(1-3 \mathrm{x}) \mathrm{Fe}^{2+}+\mathrm{S}^{2-}+2 \mathrm{xFe}^{3+} \\
\mathrm{Hg}^{2+}+\mathrm{S}^{2-} \rightarrow \mathrm{HgS} \\
\mathrm{K}_{\mathrm{sp}} \text { of } \mathrm{FeS}=\left[\mathrm{Fe}^{2+}\right]\left[\mathrm{S}^{2-}\right]=1.59 \times 10^{-19} \\
\mathrm{~K}_{\mathrm{sp}} \text { of } \mathrm{HgS}=\left[\mathrm{Hg}^{2+}\right]\left[\mathrm{S}^{2-}\right]=6.44 \times 10^{-53}
\end{gathered}
$$




\subsubsection{SEM and TEM Analysis}

Figure $6 \mathrm{~A}-\mathrm{C}$ show the SEM images of the bottom, middle, and top part of the three samples after the MPy column breakthrough occurred. As seen from Figure 6A, several hollow spherical particles (with sizes in the micron range) formed on the surface of the sample at the bottom of the MPy column. According to the energy dispersive spectroscopy (EDS) analysis, the spherical particles generated at the bottom of the dynamic column adsorbed a large amount of $\mathrm{Hg}$. It can be inferred that the acicular crystal is $\mathrm{HgS}$ according to the proportion of sulfur and mercury content. In addition, HgS substances are mainly concentrated at the bottom of the column, which is consistent with the previous XRD analysis. Figure $6 \mathrm{~B}$ shows that there are many plate-like particles on the sample surface in the middle of the column, and these micron-sized materials were tightly coated on the sample surface. Figure $6 \mathrm{C}$ shows that there are some micron scale irregular stratified structures and hollow spherical particles on the surface at the top of the MPy column. Figures 7 and 8 show the SEM and TEM images, respectively, and the energy dispersive X-ray spectroscopy (EDX) mapping image of the different elements $(\mathrm{Hg}, \mathrm{Fe}$, and S) on the used MPy obtained from the bottom of the column. It can be observed that the $\mathrm{Hg}$ and $\mathrm{S}$ elements are maintained with the same distribution, and the $S$ element has the same distribution as the Fe element, partly. The distribution of the elements can prove that the spherical substance of the sample is HgS [39], which agrees well with previous analyses. Therefore, it can be concluded that the reaction is mainly actuated by the solubility products of the sulfides and pyrrhotite, and HgS is the principle species responsible for $\mathrm{Hg}$ (II) removal.
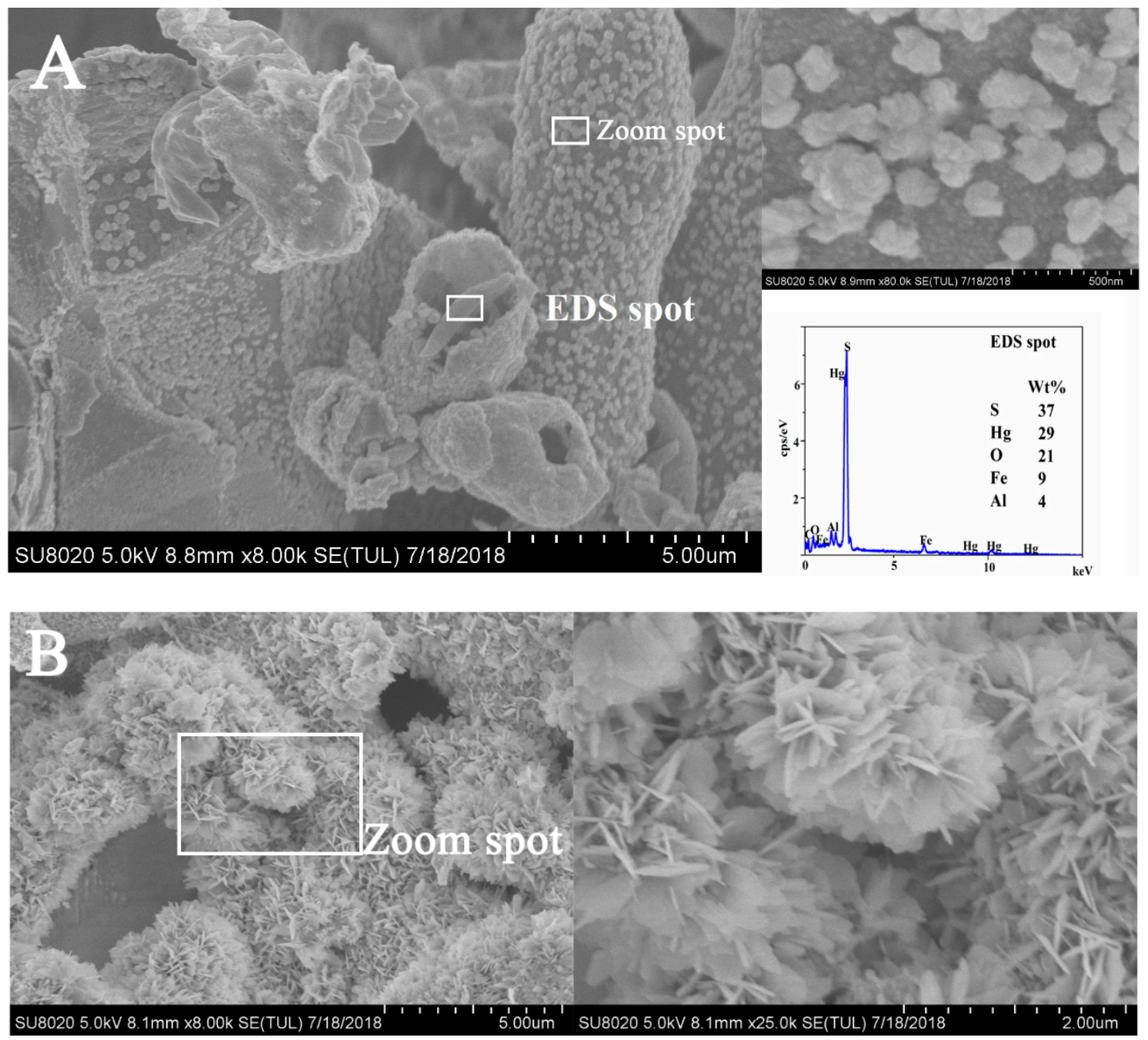

Figure 6. Cont. 


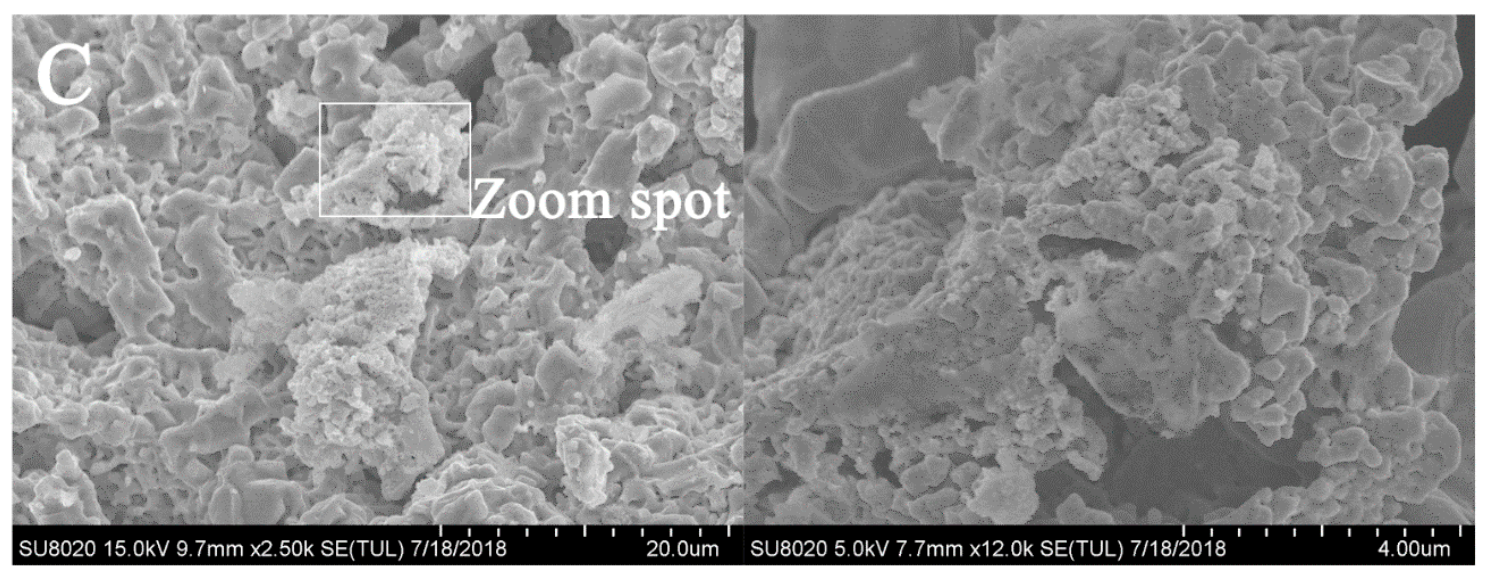

Figure 6. SEM image of the (A) used MPy at the bottom of the column, (B) used MPy at the middle of the column, (C) used MPy at the top of the column. The regions analyzed by EDS and magnified regions are labeled.

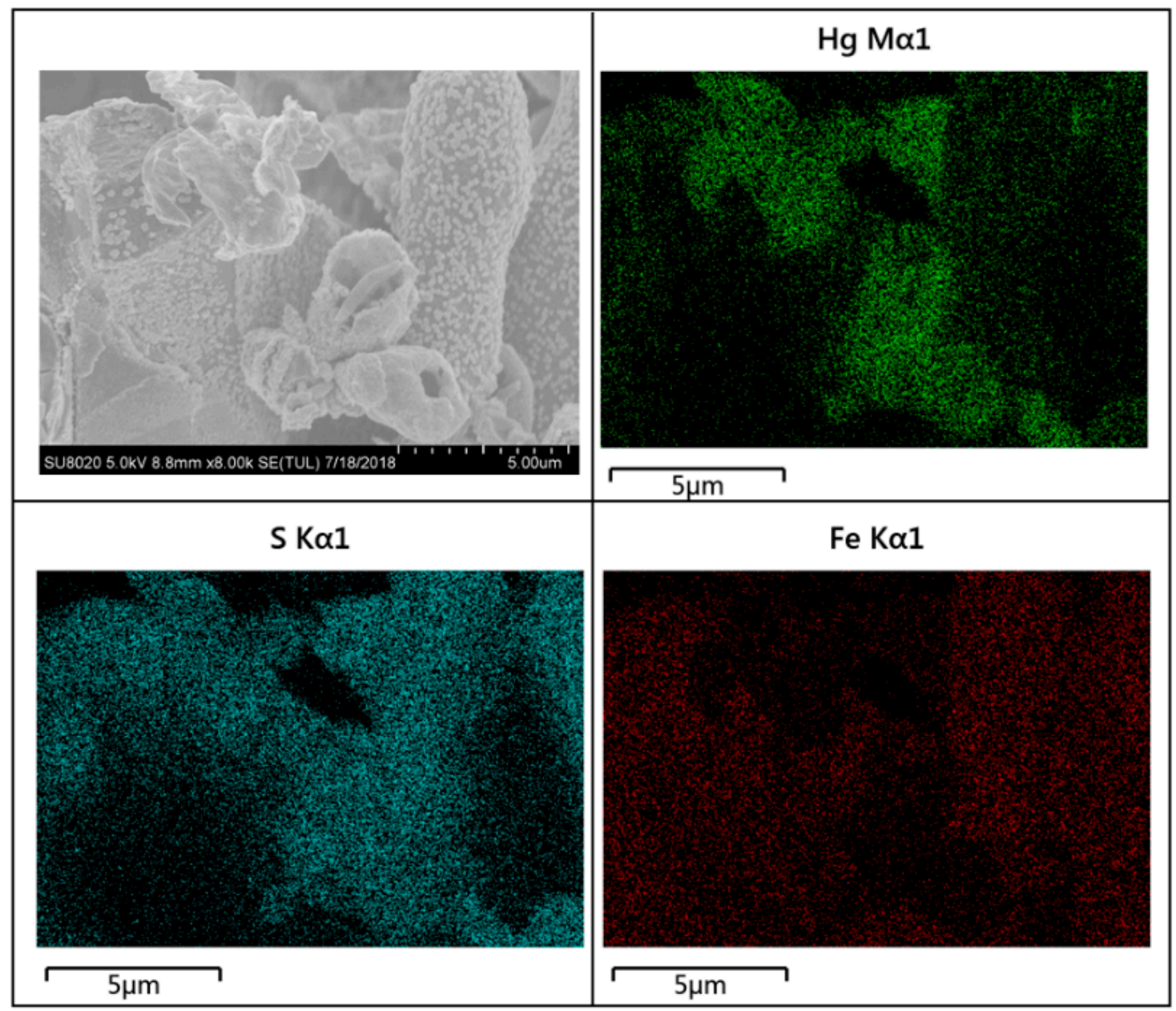

Figure 7. SEM images of the used MPy at the bottom of the column and corresponding EDX mapping images showing the $\mathrm{Hg}, \mathrm{Fe}$, and $\mathrm{S}$ distributions. 


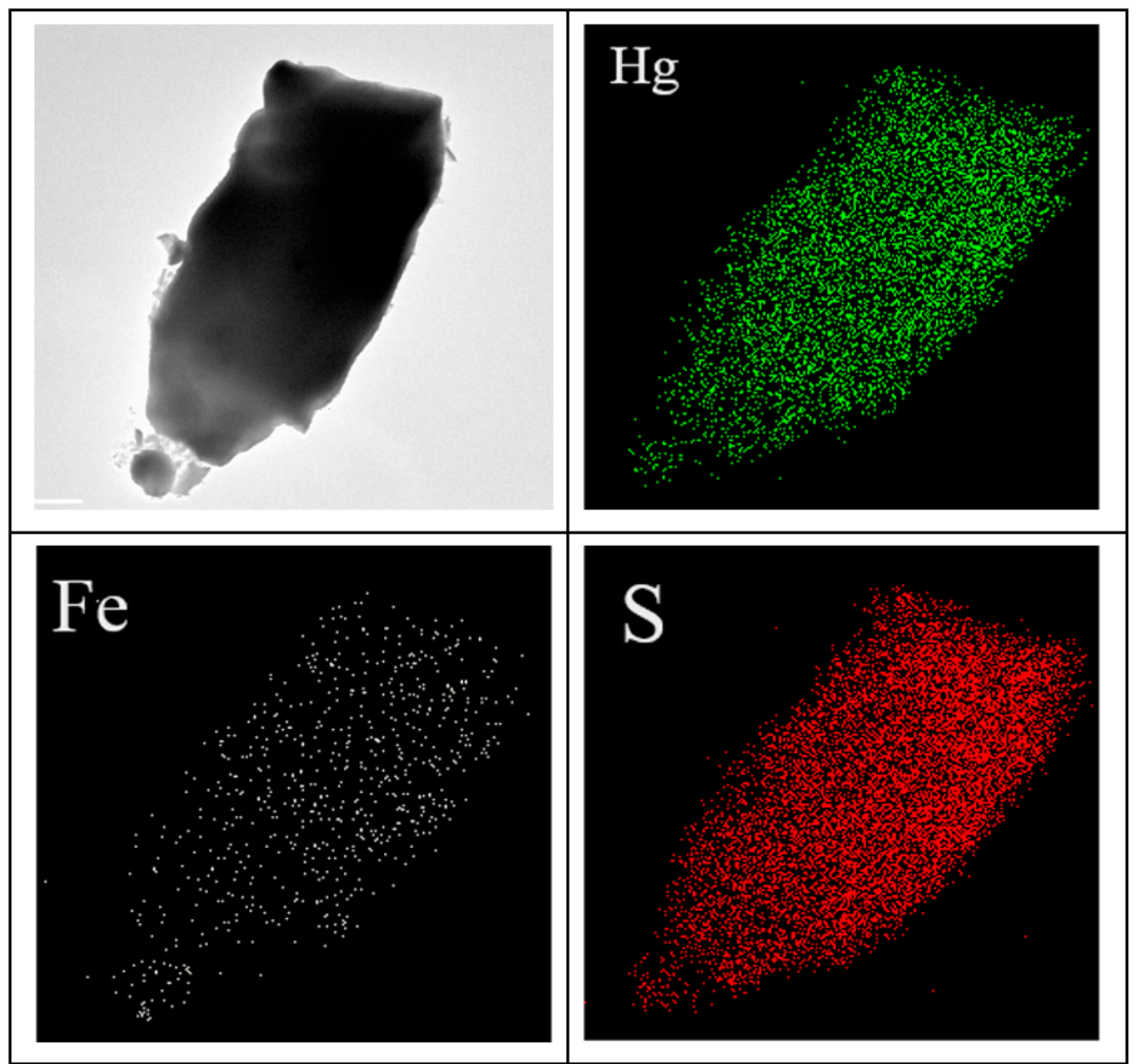

Figure 8. TEM image and the corresponding EDX mapping images showing the $\mathrm{Hg}$, $\mathrm{Fe}$, and $\mathrm{S}$ distributed on the used MPy.

\subsubsection{XPS Analysis}

XPS was used to understand the mechanism of $\mathrm{Hg}$ (II) adsorption in the MPy column by characterizing the elemental states. Figure 9 shows the Fe 2p, O 1s, S 2p and Hg 4f XPS spectra of MPy in the bottom (A), middle (B) and top (C) of the column. As presented in the figure, four major Fe $2 p$ peaks are identified from the spectrum obtained for the MPy surface. The binding energies are centered at approximately 707.2, 711.2, 720.1 and $725.1 \mathrm{eV}$. Among these peaks, the Fe 2p3/2 peak at $707.2 \mathrm{eV}$ and $\mathrm{Fe} 2 \mathrm{p}_{1 / 2}$ peak at 720.1 correspond to $\mathrm{Fe}(\mathrm{II})$ coupled with $\mathrm{S}_{2}{ }^{2-}$ and $\mathrm{SO}_{4}{ }^{2-}$, and the $\mathrm{Fe} 2 \mathrm{p} 3 / 2$ peak at $711.2 \mathrm{eV}$ and $\mathrm{Fe} 2 \mathrm{p} 1 / 2$ peak at 725.1 correspond to $\mathrm{Fe}^{3+}$ coupled with $\mathrm{O}^{2-}$ and $-\mathrm{OH}$, which indicates that part of the $\mathrm{Fe}(\mathrm{II})$ dissolved on the surface of MPy was oxidized to $\mathrm{Fe}^{3+}$, and $\mathrm{Fe}^{3+}$ was bonded with the oxygen in the solution to form iron oxide [40-42].

As observed in the figure, the $\mathrm{O} 1 \mathrm{~s}$ spectrum is best fitted with the peaks at $530.3 \mathrm{eV}, 531.3 \mathrm{eV}$, $532.1 \mathrm{eV}$ and $533.1 \mathrm{eV} . \mathrm{O}^{2-}$ corresponds to the peak at $530.1 \mathrm{eV},-\mathrm{OH}$ corresponds to the peak at $531.3 \mathrm{eV}$, $\mathrm{SO}_{4}{ }^{2-}$ corresponds to the peak at $532.1 \mathrm{eV}$, which all correspond to iron oxides. The small peak at $533.4 \mathrm{eV}$ that appeared at the bottom sample is the binding energy of the $\mathrm{O}$ of $\mathrm{SiO}_{2}$, presumably due to the residual broken glass of the supporting layer. The binding energy of the $\mathrm{O}$ of the $\mathrm{O}^{2-}$ at the bottom sample is relatively higher than that of the others, which indicates that most of the iron oxide was deposited at the bottom of the MPy column. From the bottom to the top of the column, the $\mathrm{SO}_{4}{ }^{2-}$ ion is increasing. 

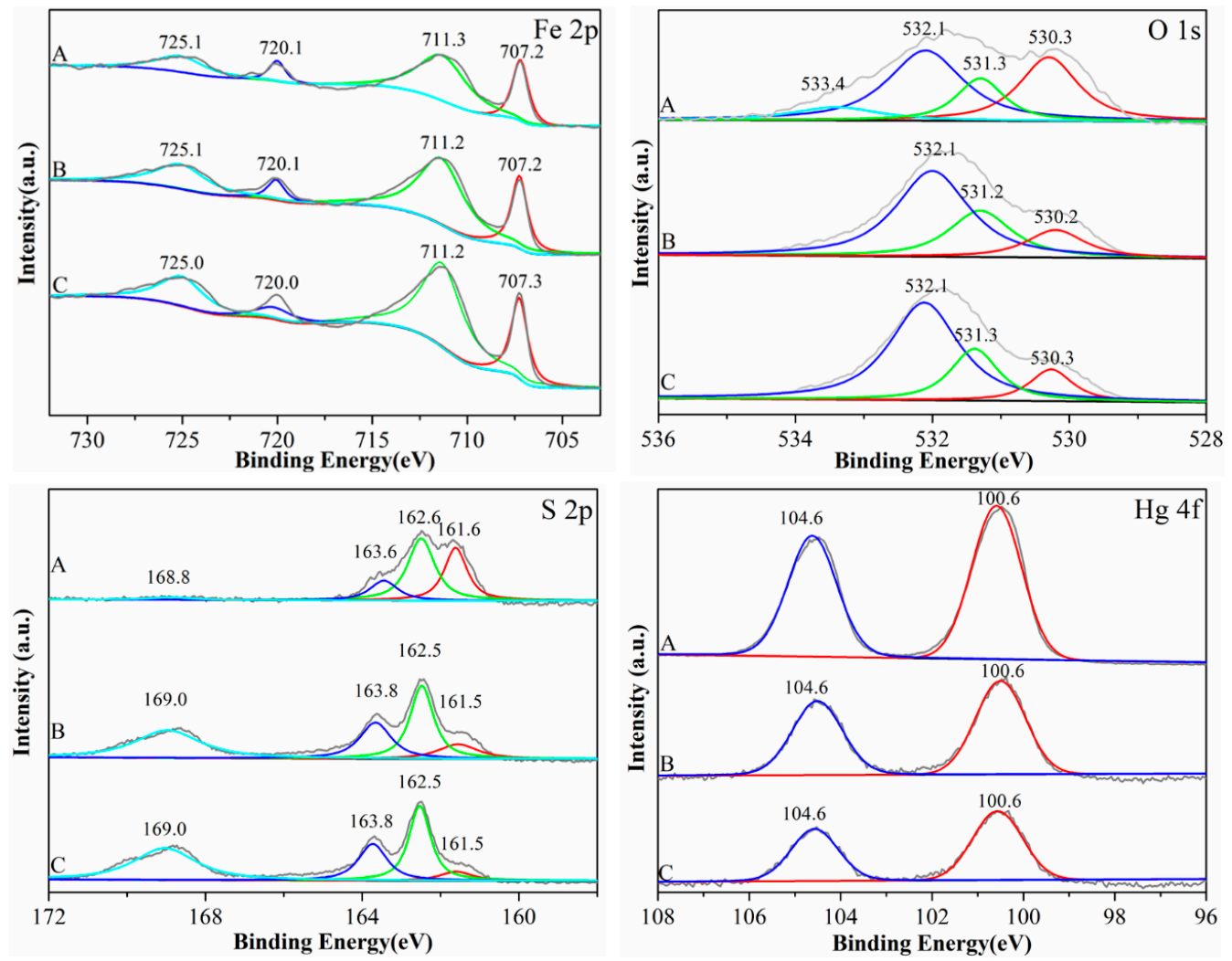

Figure 9. XPS spectra(Fe 2p, O 1s, S 2p and Hg 4f) of the MPy column ((A): bottom, (B): middle, and (C): top).

From the $S 2 p$ spectrum, we can see that there are four different forms of $S$ on the sample surface after the breakthrough of the MPy column. There are two large peaks at $161.5 \mathrm{eV}$ and $162.5 \mathrm{eV}$, where the former is $\mathrm{S} 2 \mathrm{p} 3 / 2$, and the latter is $\mathrm{S} 2 \mathrm{p} 1 / 2$. The $\mathrm{S} 2 \mathrm{p}$ survey spectrum show peaks at $161.5 \mathrm{eV}\left(\mathrm{S}^{2-}\right)$, $162.5 \mathrm{eV}\left(\mathrm{S}_{2}{ }^{2-}\right), 163.8 \mathrm{eV}\left(\mathrm{S}_{\mathrm{n}}{ }^{2-}\right)$ and $169.0 \mathrm{eV}\left(\mathrm{SO}_{4}{ }^{2-}\right)[43,44]$. The binding energy corresponding to $\mathrm{S}^{2-}$ at the bottom sample is relatively higher than that of the others, which indicates that the content of $\mathrm{S}^{2-}$ is relatively high, which prove that $\mathrm{HgS}$ precipitated at the bottom. The amount of $\mathrm{S}_{2}{ }^{2-}$ in the bottom sample is relatively low because $\mathrm{S}_{2}{ }^{2-}$ oxidized partly to disulfide and sulfate.

It can be seen from the figure that the binding energies of $\mathrm{Hg} 4 \mathrm{f5} / 2$ and $\mathrm{Hg} 4 \mathrm{f7} / 2$ are $104.6 \mathrm{eV}$ and $100.6 \mathrm{eV}$, respectively. The forms of $\mathrm{Hg}$ (II) existing on the surface of the MPy samples mainly include mercury complexes $(104.6 \mathrm{eV})$ and $\mathrm{HgS}(100.6 \mathrm{eV})$. The results show that $\mathrm{Hg}$ (II) was successfully fixed to the surface of the MPy column.

\section{Conclusions}

In the present article, the column experiments were conducted to investigate the capacity of MPy to adsorb $\mathrm{Hg}$ (II). The results show that MPy is a feasible adsorbent for the removal of $\mathrm{Hg}$ (II). The results also reveal that the capacity of MPy for mercury fixation is $54.44 \mathrm{mg} / \mathrm{g}$ when breakthrough occurred, the $\mathrm{Hg}$ (II) concentration of the MPy column effluent is lower than $0.05 \mathrm{mg} / \mathrm{L}$ when the handling capacity is less than $3274 \mathrm{BV}$, and the removal rate remains above $99 \%$. The XRD, FE-SEM, FE-TEM, and XPS analyses indicate that the $\mathrm{Hg}(\mathrm{II})$ in the solution was mainly formed by chemical reaction with MPy, and $\mathrm{Hg}(\mathrm{II})$ was removed from the solution because of the formation of $\mathrm{HgS}$ deposits on the surface of MPy. This research demonstrates that MPy is an efficient sorbent for removing $\mathrm{Hg}(\mathrm{II})$ from wastewater.

Author Contributions: Conceptualization, Y.Z. and S.P.; Methodology, P.L.; Validation, S.P., T.C. and Y.Y.; Formal Analysis, Y.Z.; Investigation, Y.Z.; Resources, S.P.; Data Curation, P.L.; Writing-Original Draft Preparation, Y.Z.; Writing-Review and Editing, Y.Z.; Visualization, Y.Z.; Supervision, S.P; Project Administration, T.C.; Funding Acquisition, S.P. All authors have read and agreed to the published version of the manuscript. 
Funding: This work was funded by the National Natural Science Foundation of China $(41772035,41702043,41402029)$.

Conflicts of Interest: The authors declare no conflict of interest.

\section{References}

1. Zahir, F.; Rizwi, S.J.; Haq, S.K.; Khan, R.H. Low dose mercury toxicity and human health. Environ. Toxicol. Pharmacol. 2005, 20, 351-360. [CrossRef]

2. Fernandes Azevedo, B.; Barros Furieri, L.; Peçanha, F.M.; Wiggers, G.A.; Vassallo, P.F.; Simões, M.R.; Fiorim, J.; de Batista, P.R.; Fioresi, M.; Rossoni, L.; et al. Toxic effects of mercury on the cardiovascular and central nervous systems. BioMed Res. Int. 2012, 2012, 949048. [CrossRef] [PubMed]

3. Bridges, C.C.; Zalups, R.K. Homocysteine, system $b^{0,+}$ and the renal epithelial transport and toxicity of inorganic mercury. Am. J. Pathol. 2004, 165, 1385-1394. [CrossRef]

4. Environmental Influences on the Immune System; Springer: Vienna, Austria, 2016.

5. Rahaman, S.A.; Roy, B.; Mandal, S.; Bandyopadhyay, S. A Kamikaze Approach for Capturing $\mathrm{Hg}^{2+} \mathrm{Ions}^{2}$ through the Formation of a One-Dimensional Metal-Organometallic Polymer. Inorg. Chem. 2016, 55, 1069-1075. [CrossRef] [PubMed]

6. Virtanen, J.K.; Rissanen, T.H.; Voutilainen, S.; Tuomainen, T.-P. Mercury as a risk factor for cardiovascular diseases. J. Nutr. Biochem. 2007, 18, 75-85. [CrossRef]

7. Houston, M.C. Role of mercury toxicity in hypertension, cardiovascular disease, and stroke. J. Clin. Hypertens. 2011, 13, 621-627. [CrossRef]

8. Gundacker, C.; Gencik, M.; Hengstschläger, M. The relevance of the individual genetic background for the toxicokinetics of two significant neurodevelopmental toxicants: Mercury and lead. Mutat. Res. 2010, 705, 130-140. [CrossRef]

9. Clarkson, T.W. The three modern faces of mercury. Environ. Health Perspect. 2002, 110, 11-23. [CrossRef]

10. Itri, F.M. Environmental Mercury Problem; CRC Press: Cleveland, OH, USA, 1972.

11. Oehmen, A.; Vergel, D.; Fradinho, J.; Reis, M.A.M. Mercury removal from water streams through the ion exchange membrane bioreactor concept. J. Hazard. Mater. 2014, 264, 65-70. [CrossRef]

12. Gupta, S.; Kershaw, S.V.; Rogach, A.L. 25th anniversary article: Ion exchange in colloidal nanocrystals. Adv. Mater. 2013, 25, 6923-6944. [CrossRef]

13. Yu, J.G.; Yue, B.Y.; Wu, X.W.; Liu, Q.; Jiao, F.; Jiang, X.; Chen, X. Removal of mercury by adsorption: A review. Environ. Sci. Pollut. Res. 2016, 23, 5056-5076. [CrossRef] [PubMed]

14. Gunatilake, S.K. Methods of removing heavy metals from industrial wastewater. J. Multidiscip. Eng. Sci. Stud. 2015, 1, 14.

15. Dash, H.R.; Das, S. Bioremediation of mercury and the importance of bacterial mer genes. Int. Biodeterior. Biodegrad. 2012, 75, 207-213. [CrossRef]

16. Inbaraj, B.S.; Sulochana, N. Mercury adsorption on a carbon sorbent derived from fruit shell of Terminalia catappa. J. Hazard. Mater. 2006, 133, 283-290. [CrossRef] [PubMed]

17. Zabihi, M.; Asl, A.H.; Ahmadpour, A. Studies on adsorption of mercury from aqueous solution on activated carbons prepared from walnut shell. J. Hazard. Mater. 2010, 174, 251-256. [CrossRef]

18. Li, Y.H.; Lee, C.W.; Gullett, B.K. Importance of activated carbon's oxygen surface functional groups on elemental mercury adsorption. Fuel 2003, 82, 451-457. [CrossRef]

19. Mohan, D.; Gupta, V.K.; Srivastava, S.K.; Chander, S. Kinetics of mercury adsorption from wastewater using activated carbon derived from fertilizer waste. Colloids Surf. A 2001, 177, 169-181. [CrossRef]

20. Vieira, R.S.; Oliveira ML, M.; Guibal, E.; Guibal, E.; Rodríguez-Castellón, E.; Beppu, M.M. Copper, mercury and chromium adsorption on natural and crosslinked chitosan films: An XPS investigation of mechanism. Colloids Surf. A 2011, 374, 108-114. [CrossRef]

21. Chandra, V.; Kim, K.S. Highly selective adsorption of $\mathrm{Hg}^{2+}$ by a polypyrrole-reduced graphene oxide composite. Chem. Commun. 2011, 47, 3942-3944. [CrossRef]

22. Duan, Y.; Han, D.S.; Batchelor, B.; Abdel-Wahab, A. Synthesis, characterization, and application of pyrite for removal of mercury. Colloids Surf. A 2016, 490, 326-335. [CrossRef]

23. Liu, S.; Li, M.; Li, S.; Yan, L. Synthesis and adsorption/photocatalysis performance of pyrite FeS 2 . Appl. Surf. Sci. 2013, 268, 213-217. [CrossRef] 
24. Weisener, C.; Gerson, A. Cu (II) adsorption mechanism on pyrite: An XAFS and XPS study. Surf. Interface Anal. 2000, 30, 454-458. [CrossRef]

25. Wang, X.; Forssberg, E.; Bolin, N.J. Adsorption of copper (II) by pyrite in acidic to neutral pH media. Scand. J. Metall. 1989, 18, 262-270.

26. Erdem, M.; Ozverdi, A. Kinetics and thermodynamics of Cd (II) adsorption onto pyrite and synthetic iron sulphide. Sep. Purif. Technol. 2006, 51, 240-246. [CrossRef]

27. Borah, D.; Senapati, K. Adsorption of Cd (II) from aqueous solution onto pyrite. Fuel 2006, 85, 1929-1934. [CrossRef]

28. Yang, Y.; Chen, T.; Li, P.; Liu, H.; Xie, J.; Xie, Q.; Zhan, X. Removal and recovery of Cu and Pb from single-metal and $\mathrm{Cu}-\mathrm{Pb}-\mathrm{Cd}-\mathrm{Zn}$ multimetal solutions by modified pyrite: Fixed-bed columns. Ind. Eng. Chem. Res. 2014, 53, 18180-18188. [CrossRef]

29. Toulmin, P., III.; Barton, P.B., Jr. A thermodynamic study of pyrite and pyrrhotite. Geochim. Cosmochim. Acta 1964, 28, 641-671. [CrossRef]

30. Janzen, M.P.; Nicholson, R.V.; Scharer, J.M. Pyrrhotite reaction kinetics: Reaction rates for oxidation by oxygen, ferric iron, and for nonoxidative dissolution. Geochim. Cosmochim. Acta 2000, 64, 1511-1522. [CrossRef]

31. Lu, P.; Chen, T.; Liu, H.; Li, P.; Peng, S.; Yang, Y. Green Preparation of Nanoporous Pyrrhotite by Thermal Treatment of Pyrite as an Effective Hg (II) Adsorbent: Performance and Mechanism. Minerals 2019, 9, 74. [CrossRef]

32. Zhu, Y.; Chen, T.; Liu, H.; Xu, B.; Xie, J. Kinetics and thermodynamics of Eu (III) and U (VI) adsorption onto palygorskite. J. Mol. Liq. 2016, 219, 272-278. [CrossRef]

33. Chen, T.H.; Wang, J.Z.; Wang, J.; Xie, J.-J.; Zhu, C.-Z.; Zhan, X.-M. Phosphorus removal from aqueous solutions containing low concentration of phosphate using pyrite calcinate sorbent. Int. J. Environ. Sci. Technol. 2015, 12, 885-892. [CrossRef]

34. Huang, S.; Ma, C.; Liao, Y.; Min, C.; Du, P.; Jiang, Y. Removal of Mercury(II) from Aqueous Solutions by Adsorption on Poly(1-amino-5-chloroanthraquinone) Nanofibrils: Equilibrium, Kinetics, and Mechanism Studies. J. Nanomater 2016, 2016, 7245829. [CrossRef]

35. GB8978. Integrated Wastewater Discharge Standard; Ministry of Ecology and Environment of the People's Republic of China: Beijing, China, 1996. Available online: http://kjs.mee.gov.cn/hjbhbz/bzwb/shjbh/swrwpfbz/ 199801/W020061027521858212955.pdf (accessed on 31 December 2019).

36. Vieira, R.S.; Beppu, M.M. Dynamic and static adsorption and desorption of $\mathrm{Hg}$ (II) ions on chitosan membranes and spheres. Water Res. 2006, 40, 1726-1734. [CrossRef]

37. Feng, Q.; Lin, Q.; Gong, F.; Sugita, S.; Shoya, M. Adsorption of lead and mercury by rice husk ash. J. Colloid Interface Sci. 2004, 278, 1-8. [CrossRef]

38. Ni, J.A. Inorganic and Analytical Chemistry; Chemical Industry Press: Beijing, China, 1998.

39. Mews, A.; Kadavanich, A.V.; Banin, U.; Alivisatos, A.P. Structural and spectroscopic investigations of CdS/HgS/CdS quantum-dot quantum wells. Phys. Rev. B 1996, 53, R13242. [CrossRef]

40. Ehrhardt, J.J.; Behra, P.; Bonnissel-Gissinger, P.; Alnot, M. XPS study of the sorption of Hg(II) onto pyrite $\mathrm{FeS}_{2}$. Surf. Interface Anal. 2000, 30, 269-272. [CrossRef]

41. Behra, P.; Bonnissel-Gissinger, P.; Alnot, M.; Revel, R.; Ehrhardt, J.J. XPS and XAS study of the sorption of $\mathrm{Hg}$ (II) onto pyrite. Langmuir 2001, 17, 3970-3979. [CrossRef]

42. Mycroft, J.R.; Nesbitt, H.W.; Pratt, A.R. X-ray photoelectron and Auger electron spectroscopy of air-oxidized pyrrhotite: Distribution of oxidized species with depth. Geochim. Cosmochim. Acta 1995, 59, 721-733. [CrossRef]

43. Buckley, A.N.; Woods, R. X-ray photoelectron spectroscopy of oxidised pyrrhotite surfaces. Appl. Surf. Sci. 1985, 20, 472-480. [CrossRef]

44. Pratt, A.R.; Muir, I.J.; Nesbitt, H.W. X-ray photoelectron and Auger electron spectroscopic studies of pyrrhotite and mechanism of air oxidation. Geochim. Cosmochim. Acta 1994, 58, 827-841. [CrossRef]

(C) 2019 by the authors. Licensee MDPI, Basel, Switzerland. This article is an open access article distributed under the terms and conditions of the Creative Commons Attribution (CC BY) license (http://creativecommons.org/licenses/by/4.0/). 